\title{
278. Lokale Antibiotica-Behandlung mit protrahierter Wirkstoff- Freisetzung in der Weichteilchirurgie
}

\author{
D. Sachweh
}

Chirurgische Klinik am Jung-Stilling-Krankenhaus Siegen, Wickernstraße 40, D-5900 Siegen

\section{Local Antibiotic Treatment with Protracted Release of the Active Constituent in Soft Tissue Surgery}

Summary. The use of a combination of primary wound closure and implantation of Septopal chains in primarily contaminated wounds is compared with conventional treatment and demonstrated by examples of the sacral cavity after abdominoperineal rectum amputation and the wound after complicated appendicitis. Using the new therapeutic concept, the infection rate was reduced from $21 \%$ to $7 \%$ in gangrenous appendicitis, from $42 \%$ to $21 \%$ in perforating appendicitis and from $54 \%$ to $5 \%$ in perineal wounds. The stay in hospital was considerably shortened. Unsuccessful therapy is usually attributable to technical mistakes in the use of this method.

Key words: Infection rate - Contaminated wounds - Septopal chain.

Zusammenfassung. Bei primär kontaminierten Wunden, dargestellt an der Sacralhöhle nach abdominaler perinealer Rectumamputation und der Wunde nach komplizierter Appendicitis, wird die bisherige konventionelle Behandlung der Kombination des primären Wundverschlusses mit Septopalketteneinlage gegenübergestellt. Durch das neue Therapiekonzept konnte die Infektionsrate nach Appendicitis gangraenosa von 21 auf 7 , nach Appendicitis perforate von 42 auf $21 \%$ und bei der perinealen Wunde von 54 auf $5 \%$ gesenkt werden. Die stationäre Verweildauer wurde erheblich verkürzt. Therapieversager sind in der Regel auf technische Fehler der Methode zurückzuführen.

Schlïsselwörter: Infektionsrate bei kontaminierten Wunden - Septopalketten.

\section{Behandlung von Weichteilinfektionen mit Septopalketten}

\author{
R. Bötticher \\ Chirurgische Klinik I am Stadtkrankenhaus Fürth, D-8510 Fürth
}

\section{Treatment of Soft Tissue Infections with Septopal}

Summary. Septopal chains were inserted as a preventive measure in 87 cases of perforated appendicitis with bacterial contamination of the abdominal wall. There was a wound infection in 18 cases. The wound was closed after incision of 31 soft tissue abscesses in general anaesthesia and insertion of Septopal chains. The chains were removed 7-10 days later. Healing by first intention was seen in 23 cases.

Key words: Wound infection - Soft-tissue infection - Septopal chains.

Zusammenfassung. Bei 87 Patienten mit perforierter Appendicitis und kontaminierten Operationswunden wurden Septopalketten subcutan eingelegt. Nur in 18 Fällen kam es zu Sekundärheilungen. Nach Spaltung von 31 Weichteilabscessen in Allgemeinnarkose kam es nach primärem Wundverschluß über der Kette nur 8mal nicht zu einer Primärheilung. Ähnlich günstige Erfahrungen haben wir bei Oberschenkelamputationen von Durchblutungsgestörten gemacht.

Schliisselwörter: Wund- und Weichteilinfektionen - Septopalketten. 